\title{
Population fluctuation and faunal indices of aphids (Hemiptera, Aphididae) in peach orchards in Araucária, PR
}

\author{
Schuber, JM. ${ }^{\text {a* }}$, Monteiro, LB. ${ }^{\mathrm{a}}$, Poltronieri, $A S .^{\mathrm{a}}$, Carvalho, $R C Z .^{\mathrm{b}}$ and Zawadneak, MAC. ${ }^{\mathrm{c}}$ \\ ${ }^{a}$ Laboratório de Manejo Integrado de Pragas, Departamento de Fitotecnia e Fitossanitarismo, \\ Universidade Federal do Paraná - UFPR, \\ Rua dos Funcionários, 1540, Juvevê, CEP 80035-050, Curitiba, PR, Brazil \\ ${ }^{\text {b} C e n t r o ~ d e ~ D i a g n o ́ s t i c o ~ M a r c o s ~ E n r i e t t i, ~ S e c r e t a r i a ~ d a ~ A g r i c u l t u r a ~ e ~ d o ~ A b a s t e c i m e n t o ~ d o ~ P a r a n a ́ ~-~ S E A B-P R, ~}$ \\ Rua Jaime Balão, 575, Juvevê, CEP 80040-340, Curitiba, PR, Brazil \\ 'Laboratório de Parasitologia Agrícola, Departamento de Patologia Básica, Universidade Federal do Paraná - UFPR, \\ Rua Coronel Francisco H. dos Santos, s/n, Jardim das Américas, CEP 81531990, Curitiba, PR, Brazil \\ *e-mail: joseliaschuber@yahoo.com.br
}

Received February 21, 2008 - Accepted May 20, 2008 - Distributed August 31, 2009

(With 2 figures)

\begin{abstract}
Aphids are sap-sucking insects that mainly attack shoots and young leaves of peach trees and many other plant species; however, knowledge of the Brazilian aphid fauna is scant. The objective of this study was to identify aphid species collected in peach orchards (Prunus persica Batsch) and to determine their faunal indices for occurrence and dominance. The experiment was conducted from July 2005 to September 2006 in six Chimarrita peach orchards in the municipality of Araucária, PR, Brazil. The survey of aphid species was conducted by visual samplings on peach trees and using Möericke-type yellow traps containing water. A faunal analysis was made using aphid occurrence and dominance indices. Brachycaudus persicae (Passerini, 1860) was the only aphid species that was found colonizing peach in Araucária/PR. Although most aphids collected were classified as rare, some can be considered potential peach colonizers, such as Myzus persicae (Sulzer, 1776) which was given the status of common or intermediate in some of the orchards studied. The population fluctuation of aphids showed a negative correlation with rainfall and positive correlation with temperature and relative humidity.
\end{abstract}

Keywords: Prunus persica, Aphididae, visual sampling, Möericke trap.

\section{Flutuação populacional e índices faunísticos de afídeos (Hemiptera, Aphididae) em pomares de pessegueiros em Araucária, PR}

\section{Resumo}

Os afídeos são insetos sugadores de seiva que atacam principalmente brotações e folhas novas de pessegueiros e de diversas outras espécies vegetais, porém o conhecimento sobre a afidofauna brasileira é escasso. O objetivo deste trabalho foi identificar as espécies de afídeos coletadas em pomares de pessegueiros (Prunus persica Batsch) e analisar os índices faunísticos de ocorrência e dominância. O experimento foi realizado de julho de 2005 a setembro de 2006 em seis pomares de pessegueiros da cultivar Chimarrita no município de Araucária, PR. O levantamento das espécies de afídeos foi realizado por meio de amostragens visuais em pessegueiros e armadilhas amarelas de água do tipo Möericke. Brachycaudus persicae (Passerini, 1860) foi a única espécie de afídeo encontrada colonizando pessegueiros em Araucária, PR. Apesar da maioria das espécies de afídeos coletadas serem classificadas como raras, algumas podem ser consideradas colonizadoras potenciais de pessegueiros como Myzus persicae (Sulzer, 1776) que recebeu o status de comum ou intermediária em alguns dos pomares estudados. A flutuação populacional de afídeos apresentou uma correlação negativa com a precipitação pluviométrica e positiva com a temperatura e a umidade relativa do ar.

Palavras-chave: Prunus persica, Aphididae, amostragem visual, armadilha Möericke.

\section{Introduction}

The peach tree (Prunus persica Batsch) is a temperate climate fruit tree cultivated in southern and southeastern Brazil (Junqueira and Peetz, 2003). In the state of Paraná, there are about 1,745 ha of peach orchards

distributed as small properties, which yield a total of 19,000 tons of peaches per year (Junqueira and Peetz, 2003). The highest producing area is located in the southwest region of the state, and in the municipalities 
of Lapa, Araucária, Irati, Guarapuava, Ponta Grossa and Cornélio Procópio (Junqueira and Peetz, 2003).

In some of these peach-producing regions, the aphids (Hemiptera: Aphididae) are considered secondary pests (Botton et al., 2003). These insects wrinkle and deform the leaves (Gallo et al., 2002), as well as affect the development of the apical shoot, stimulate the growth of side branches and change the plant architecture (Salles, 1998).

The population fluctuation, migration and flight activity of aphids vary during the year, because they are affected by various biotic and abiotic factors, among them being the occurrence of rains, winds, variations in temperature and lack of food (Lazzari, 1985). Furthermore, the polyphagous species can be distributed more widely, both temporally and spatially (Lazzari and Lazzarotto, 2005).

There is information in the literature about the damage caused by aphids of economic importance and their control. However, there is scarce data about the aphid species occurring in fruit crops in Brazil (Sousa-Silva and Ilharco, 1995; Ferreira and Barbosa, 2002). For the peach crop, four aphid species have been identified: Brachycaudus helichrysi (Kaltenbach, 1843), Brachycaudus persicae (Passerini, 1860), Myzus persicae (Sulzer, 1776) and Toxoptera citricida (Kirkaldy, 1907) (Souza-Silva and Ilharco, 1995). The aphid species that occur in Paraná state are unknown, despite the economic importance of this fruit for the region. In this research, the main objective was to identify the aphid species present in peach orchards in the municipality of Araucária (PR) and to analyze their faunal indices for occurrence and dominance.

\section{Materials and Methods}

The experiment was conducted from July 2005 to September 2006 in Araucária, PR (latitude: $25^{\circ} 35$ ' 35' S and longitude: $49^{\circ} 24^{\prime} 37^{\prime \prime} \mathrm{W}$ and altitude: $897 \mathrm{~m}$ ). The survey was carried out in six commercial peach orchards of Chimarrita cultivar, three conducted by the production system Good Agricultural Practices (GAP) and three by the system Conventional Production (CP). The characteristics of the orchards are presented in Table 1. The rainfall, relative humidity and daily temperature data were obtained from the Paraná Meteorological System (Simepar, 2006).

\subsection{Visual sampling on the peach trees}

Five peach trees per orchard were selected randomly and the presence of aphid colonies around the plant to a height of $1.70 \mathrm{~m}$ was determined weekly. All branches infested by aphids were cut with pruning scissors, placed in plastic bags properly identified, and transported to the laboratory for identification and counting of the specimens. The adults (apterous and winged) were fixed in $70 \%$ ethanol for later identification.

\subsection{Möericke traps}

Four Möericke traps $(29 \times 20 \times 6 \mathrm{~cm})$ were installed in between rows of each orchard; they were suspended by a wooden support at a mean height of $90 \mathrm{~cm}$ from the ground. Each trap contained $1.5 \mathrm{~L}$ of water and $1 \mathrm{~mL}$ of colourless neutral detergent to break the surface tension. The insects were removed weekly, with forceps and transferred to plastic containers containing 70\% ethanol. After removing the samples, the traps were washed and the water and detergent replaced.

\subsection{Preparation and identification of material}

The aphids collected were separated into morphospecies using a stereomicroscope in the laboratory and then mounted on permanent slides, following the method of Martin (1983) with the following adjustments: the specimens (morphospecies) were placed in test tubes $(5 \mathrm{~mL})$ containing potassium hydroxide (10\%) and kept in a waterbath for five minutes for tissue maceration. Subsequently, the specimens were transferred to a series of baths in distilled water for ten minutes, then in $70 \%$ alcohol for about ten minutes, followed by decanting in glacial acetic acid until dehydrated. Afterwards, they were transferred to clove oil, for at least ten minutes, and then mounted on permanent slides using Canadian balsam. The identification was performed under a light microscope using identification keys proposed by Holman (1974), Martin (1983), Blackman and Eastop (1984), Costa et al., (1993), Foottit and Richards (1993) and Gualtieri and Mc Leod (1994).

\subsection{Faunal analyses}

Faunal analysis was carried out using occurrence and dominance indices according to Palma (1975) apud Abreu and Nogueira (1989). The occurrence index of aphid species was calculated by the formula:

Table 1. Characterization of peach orchards in Araucária, Paraná, Brazil.

\begin{tabular}{lcccccc}
\hline \multicolumn{1}{c}{ Orchards } & GAP1 $^{1}$ & GAP2 $^{1}$ & GAP3 $^{1}$ & CP1 $^{2}$ & CP2 $^{2}$ & CP3 $^{2}$ \\
\hline Coordinates & $25^{\circ} 33^{\prime} \mathrm{S}$ & $25^{\circ} 31^{\prime} \mathrm{S}$ & $25^{\circ} 36^{\prime} \mathrm{S}$ & $25^{\circ} 35^{\prime} \mathrm{S}$ & $25^{\circ} 30^{\prime} \mathrm{S}$ & $25^{\circ} 33^{\prime} \mathrm{S}$ \\
& $49^{\circ} 33^{\prime} \mathrm{W}$ & $49^{\circ} 27^{\prime} \mathrm{W}$ & $49^{\circ} 25^{\prime} \mathrm{W}$ & $49^{\circ} 31^{\prime} \mathrm{W}$ & $49^{\circ} 26^{\prime} \mathrm{W}$ & $49^{\circ} 31^{\prime} \mathrm{W}$ \\
Altitude & $915 \mathrm{~m}$ & $944 \mathrm{~m}$ & $911 \mathrm{~m}$ & $922 \mathrm{~m}$ & $926 \mathrm{~m}$ & $934 \mathrm{~m}$ \\
Area (ha) & 0.44 & 0.30 & 0.30 & 0.48 & 0.37 & 0.75 \\
Spacing (m) & $6 \times 4$ & $6 \times 4$ & $6 \times 4$ & $6 \times 8$ & $6 \times 4$ & $6 \times 4$ \\
Number of plants & 183 & 127 & 125 & 100 & 155 & 312 \\
Age (years) & 6 & 8 & 6 & 10 & 11 & 5 \\
\hline
\end{tabular}

${ }^{1}$ Good Agricultural Practices (GAP); and ${ }^{2}$ Conventional Production (CP). 
$\mathrm{C}(\%)=($ nasp $* 100) /$ na, in which nasp $=$ number of samples with the species occurrence and na $=$ total number of samples. Using this method, the following classes were established: accidental, where species are present in less than $25 \%$ of the collections; accessory, where species are present in 25 to $50 \%$ of the sampling dates; and constant, where species are present in more than $50 \%$ of the collection dates. Dominance was obtained using the formula: $\mathrm{D}(\%)=\left(\mathrm{sp}^{*} 100\right) / \mathrm{n}$, in which $\mathrm{sp}=$ number of individuals of a species; $\mathrm{n}=$ total number of individuals. The value obtained was classified as: accidental, where species represent 0.0 to $2.5 \%$ of total aphids; accessory, where species represent 2.6-5.0\% of the total aphids; and dominant, where species represent $5.1-100 \%$ of the total aphids.

The combination of the occurrence and dominance indices can be used for a general classification or status of the species in: common species (constant + dominant) [C], intermediate species (accidental + dominant; accidental + accessory; accessory + accessory; accessory + dominant) $[\mathrm{I}]$ and rare species (accidental + accidental) $[\mathrm{R}]$.

\subsection{Statistical analyses}

The effects of the climatic factors on the total numbers of aphids sampled weekly were determined by Poisson regression analysis and Pearson's correlation between means of rainfall, temperature and relative humidity and number of aphids. The level of statistical significance was set at $\mathrm{p}=0.05$.

\section{Results}

The occurrence of $B$. persicae colonizing peach trees in Araucária, PR was observed. Colonies with 58 and 41 specimens were found respectively in August and September of 2006, on the branches of that year, in two of the six orchards studied.

Using Möericke traps, 13,056 specimens of aphids in the six peach orchards were collected, representing $99.25 \%$ of total aphid collection in the period of July 2005 to September 2006. A total of 32 species, belonging to 21 genera, were trapped, where two species were identified only to the level of tribe (Macrosiphini and Aphidini) (Table 2).

The species trapped with higher frequencies were: Uroleucon ambrosiae (Thomas, 1878) (35.75\%), Brevicoryne brassicae (Linnaeus, 1758) (20.47\%), Aphis spiraecola Patch, 1914 (19.41\%), T. citricida (10.42\%), M. Zpersicae (6.39\%), Macrosiphum rosae (Linnaeus, 1758) (1.95\%) and Aulacorthum solani (Kaltenbach, 1843) $(1.19 \%)$. The other species occurred in frequencies below $1 \%$ (Table 2). Among the species caught, eight are considered polyphagous according to Blackman and Eastop (1984): Aphis gossypii Glover, 1877, Aphis solanella Theobald, 1914, A. spiraecola, Macrosiphum euphorbiae (Thomas, 1878), Myzus ornatus Laing, 1932, A. solani, M. persicae and Toxoptera aurantii (Boyer de Fonscolombe, 1841); the latter four species occurred in all the orchards studied (Table 2).
B. persicae was collected on the peach trees with Möericke traps, probably due to its low population density; colonies found on $P$. persica during visual sampling were small and present in only two orchards. The other species collected with Möericke traps probably originated from invasive plants present in the orchards, as well from other vegetation and/or other neighboring crops.

The results of the faunistic analysis are presented in Table 3. A. spiraecola was considered common in all the orchards studied, whereas U. ambrosiae was classified as common in five of the six orchards. These two species accounted for more than $50 \%$ of total aphids caught and occurred on almost all the collection dates. T. citricida and $B$. brassicae were classified as common in two orchards, while $M$. persicae was common only in one orchard. The species $B$. persicae was given the status of rare in one of the orchards and intermediate in another (Table 3).

Based on regression analysis, it was seen that the aphids were significantly influenced by climatic factors $(\mathrm{p}<0.02)$. The equation of the fitted model was:

aphids $=$

$\exp ^{(1.8722486+\operatorname{TEMP}(0.0069455)+\operatorname{PREC}(-0.0282695)+\mathrm{RH}(0.0501702))}$

where TEMP is temperature, PREC, precipitation and RH, relative humidity. An inverse correlation was determined for rainfall and a positive correlation for temperature and relative humidity.

Overall, it was observed that when the rainfall was extremely low, in the months from May to September of 2006, combined with a decrease in temperature, there was an increase in the number of total aphids trapped (Figure 1). The population fluctuation of the two most frequent species, $U$. ambrosiae and A. spiraecola, resulted in two peaks for $U$. amborosiae (December 2005 and June 2006, with 1,222 and 1,622 specimens, respectively) and one peak for A. spiraecola (June 2006 with 574 pecimens). Both species showed an inverse relationship between population peak and rainfall (Figure 2).

\section{Discussion}

This study showed that $B$. persicae is the only aphid species colonizing $P$. persica in Araucária, PR. This species was reported as a pest of the crop by Blackman and Eastop (1984), as well as by Souza-Silva and Ilharco (1995) who also cited the occurrence of $B$. helichrysi in Brazilian peach orchards. However, the aphid Brachycaudus schwartzi (Börner, 1931) was not observed colonizing peach in Araucária, diverging from the results of other authors who found this species in other Brazilian locations: Jacuí, MG (Auad, 1996), São Paulo, SP (Mansur, 1971) and Curitiba, PR (Bartoszeck, 1976).

Regarding the faunal analysis, similar results were found by Lazzari and Lazzarotto (2005), who colleted in Serra do Mar 8,134 specimens and identified 87 species of aphids, using Möericke traps. The diversity and abundance of aphids trapped may be explained by trap 
Table 2. Frequencies of aphid species collected with Möericke traps in peach orchards conducted by the production system Good Agricultural Practices (GAP) and system Conventional Production (CP). Araucária, PR. July 2005 to September 2006.

\begin{tabular}{|c|c|c|c|c|c|c|c|c|}
\hline \multirow[t]{2}{*}{ Species } & \multicolumn{6}{|c|}{ Orchards } & \multirow[t]{2}{*}{ Total } & \multirow[t]{2}{*}{$\%$} \\
\hline & GAP1 & GAP2 & GAP3 & CP1 & CP2 & CP3 & & \\
\hline Aphis amaranthi Holman & 0 & 0 & 0 & 2 & 0 & 0 & 2 & 0.02 \\
\hline Aphis forbesi Weed & 0 & 0 & 0 & 0 & 0 & 1 & 1 & 0.01 \\
\hline Aphis gossypii Glover ${ }^{1}$ & 0 & 0 & 16 & 0 & 0 & 0 & 16 & 0.12 \\
\hline Aphis nerii Boyer de Fonscolombe & 1 & 0 & 0 & 0 & 0 & 4 & 5 & 0.04 \\
\hline Aphis solanella Theobald ${ }^{1}$ & 0 & 1 & 0 & 0 & 0 & 7 & 8 & 0.06 \\
\hline Aphis spiraecola Patch $^{1}$ & 460 & 850 & 233 & 438 & 233 & 320 & 2534 & 19.41 \\
\hline Aulacorthum solani (Kaltenbach) ${ }^{1}$ & 50 & 25 & 3 & 26 & 19 & 32 & 155 & 1.19 \\
\hline Brachycaudus helichrysi (Kaltenbach) & 0 & 17 & 3 & 0 & 2 & 0 & 22 & 0.17 \\
\hline Brevicoryne brassicae (Linnaeus) & 168 & 1087 & 58 & 1148 & 110 & 101 & 2672 & 20.47 \\
\hline Capitophorus elaeagani (del Guercio) & 0 & 0 & 3 & 0 & 0 & 0 & 3 & 0.02 \\
\hline Cinara atlantica (Wilson) & 2 & 5 & 4 & 3 & 0 & 0 & 14 & 0.11 \\
\hline Dysaphis cynarae (Theobald) & 0 & 0 & 0 & 1 & 0 & 1 & 2 & 0.02 \\
\hline Dysaphis emicis (Mimeur) & 0 & 0 & 0 & 9 & 9 & 0 & 18 & 0.14 \\
\hline Eulachnus thunbergii Wilson & 0 & 1 & 0 & 0 & 0 & 0 & 1 & 0.01 \\
\hline Geopemphigus floccosus (Moreira) & 0 & 15 & 0 & 0 & 0 & 0 & 15 & 0.11 \\
\hline Greenidea psidii van der Goot & 0 & 1 & 0 & 0 & 0 & 0 & 1 & 0.01 \\
\hline Hyperomyzus lactucae (Linneaus) & 0 & 0 & 0 & 2 & 0 & 3 & 5 & 0.04 \\
\hline Lipaphis erysimi (Kaltenbach) & 0 & 0 & 0 & 5 & 0 & 0 & 5 & 0.04 \\
\hline Macrosiphum euphorbiae (Thomas) ${ }^{1}$ & 0 & 7 & 14 & 2 & 10 & 0 & 33 & 0.25 \\
\hline Macrosiphum rosae (Linnaeus) & 2 & 177 & 21 & 54 & 0 & 0 & 254 & 1.95 \\
\hline Microparsus (Picturaphis) brasiliensis (Moreira) & 0 & 1 & 0 & 0 & 0 & 0 & 1 & 0.01 \\
\hline Myzus ornatus Laing ${ }^{1}$ & 0 & 0 & 0 & 13 & 1 & 0 & 14 & 0.11 \\
\hline Myzus persicae (Sulzer) ${ }^{1}$ & 114 & 112 & 67 & 524 & 10 & 2 & 834 & 6.39 \\
\hline Neophyllaphis (Chileaphis) podocarpini Carrillo & 0 & 0 & 12 & 1 & 0 & 2 & 15 & 0.11 \\
\hline Rhopalosiphum maidis (Fitch) & 11 & 5 & 0 & 24 & 0 & 3 & 43 & 0.33 \\
\hline Rhopalosiphum padi (Linnaeus) & 0 & 0 & 0 & 42 & 4 & 0 & 46 & 0.35 \\
\hline Tetraneura nigriabdominalis (Sasaki) & 3 & 16 & 12 & 3 & 2 & 13 & 49 & 0.38 \\
\hline Toxoptera aurantii (Boyer de Fonscolombe) ${ }^{1}$ & 3 & 43 & 28 & 20 & 3 & 13 & 110 & 0.84 \\
\hline Toxoptera citricida (Kirkaldy) & 80 & 235 & 149 & 626 & 233 & 38 & 1361 & 10.42 \\
\hline Tuberculatus (Nippocallis) kuricola Matsumura & 9 & 0 & 0 & 0 & 0 & 0 & 9 & 0.07 \\
\hline Uroleucon ambrosiae (Thomas) & 834 & 1026 & 445 & 1414 & 501 & 447 & 4667 & 35.75 \\
\hline Uroleucon sonchi (Linnaeus) & 0 & 0 & 65 & 31 & 10 & 0 & 106 & 0.81 \\
\hline n.i. 1 (Aphidini) $)^{2}$ & 0 & 1 & 0 & 0 & 0 & 0 & 1 & 0.01 \\
\hline n.i. 2 (Macrosiphini) ${ }^{2}$ & 0 & 14 & 8 & 3 & 2 & 7 & 34 & 0.26 \\
\hline Total & 1737 & 3639 & 1141 & 4391 & 1149 & 994 & 13056 & 100.00 \\
\hline
\end{tabular}

${ }^{1}$ Polyphagous species according to Blackman and Eastop (1984); and ${ }^{2}$ Species identified to the level of tribe.

attraction characteristics, because the yellow colour attracts not only aphids, that are colonizing nearby plants, but also those in migration. That is, not all aphids caught by traps land on plants and establish colonies. This was characterized in the results of the present study, where by visual sampling only $B$. persicae was captured, demonstrating the importance of this method for the collection of aphid species that effectively colonize $P$. persica.
The occurrence of A. spiraecola and U. ambrosiae in larger quantities in the present study may be related to the higher diversity of Asteraceae family plants in the orchards, as these aphid species colonize preferably plants from that family (Blackman and Eastop, 1984; SouzaSilva and Ilharco, 1995). A. spiraecola was a common species in the six orchards studied, probably because it is polyphagous and is highly attracted to the yellow traps (Webb et al., 1994). Although the majority of the spe- 
Table 3. Faunal indices of aphids sampled by visual observations and traps Möericke traps in peach orchards, conducted by the production system Good Agricultural Practices (GAP) and system Conventional Production (CP), with their occurrence and dominance status, according to the classification of Palma ${ }^{1}$. Araucária, PR. July 2005 to September 2006.

\begin{tabular}{|c|c|c|c|c|c|c|c|c|c|c|c|c|c|c|c|c|c|c|}
\hline \multirow[t]{3}{*}{ Species } & \multicolumn{18}{|c|}{ Orchards/Status } \\
\hline & \multicolumn{3}{|c|}{ GAP1 } & \multicolumn{3}{|c|}{ GAP2 } & \multicolumn{3}{|c|}{ GAP3 } & \multicolumn{3}{|c|}{ CP1 } & \multicolumn{3}{|c|}{ CP2 } & \multicolumn{3}{|c|}{ CP3 } \\
\hline & $\mathbf{C}^{1}$ & $\mathbf{D}^{2}$ & $\mathbf{S}^{\mathbf{3}}$ & $\mathbf{C}^{1}$ & $\mathbf{D}^{2}$ & $\mathbf{S}^{3}$ & $\mathrm{C}^{1}$ & $D^{2}$ & $\mathbf{S}^{\mathbf{3}}$ & $\mathbf{C}^{1}$ & $\mathbf{D}^{2}$ & $\mathbf{S}^{3}$ & $\mathrm{C}^{1}$ & $\mathbf{D}^{2}$ & $\mathbf{S}^{3}$ & $\mathbf{C}^{1}$ & $\mathbf{D}^{2}$ & $\mathbf{S}^{3}$ \\
\hline Aphis amaranthi & - & - & - & - & - & - & - & - & - & $\mathrm{x}$ & $\mathrm{a}$ & $\mathrm{r}$ & - & - & - & - & - & - \\
\hline Aphis forbesi & - & - & - & - & - & - & - & - & - & - & - & - & - & - & - & $\mathrm{x}$ & $\mathrm{a}$ & $\mathrm{r}$ \\
\hline Aphis gossypii & - & - & - & - & - & - & $\mathrm{x}$ & $\mathrm{a}$ & $\mathrm{r}$ & - & - & - & - & - & - & - & - & - \\
\hline Aphis nerii & $\mathrm{x}$ & $\mathrm{a}$ & $\mathrm{r}$ & - & - & - & - & - & - & - & - & - & - & - & - & $\mathrm{x}$ & $\mathrm{a}$ & $\mathrm{r}$ \\
\hline Aphis solanella & - & - & - & $\mathrm{x}$ & $\mathrm{a}$ & $\mathrm{r}$ & - & - & - & - & - & - & - & - & - & $\mathrm{x}$ & $\mathrm{a}$ & $\mathrm{r}$ \\
\hline Aphis spiraecola & $\mathrm{z}$ & d & $\mathrm{c}$ & $\mathrm{z}$ & d & $\mathrm{c}$ & $\mathrm{z}$ & $\mathrm{d}$ & $\mathrm{c}$ & $\mathrm{z}$ & d & $\mathrm{c}$ & $\mathrm{z}$ & d & $\mathrm{c}$ & $\mathrm{z}$ & $\mathrm{d}$ & $\mathrm{c}$ \\
\hline Aulacorthum solani & $\mathrm{x}$ & $\mathrm{s}$ & $\mathrm{i}$ & $\mathrm{x}$ & $\mathrm{a}$ & $\mathrm{r}$ & $\mathrm{x}$ & $\mathrm{a}$ & $\mathrm{r}$ & $\mathrm{y}$ & $\mathrm{a}$ & $\mathrm{i}$ & $\mathrm{x}$ & $\mathrm{a}$ & $\mathrm{r}$ & $\mathrm{x}$ & $\mathrm{s}$ & $\mathrm{i}$ \\
\hline Brachycaudus helichrysi & - & - & - & $\mathrm{x}$ & $\mathrm{a}$ & $\mathrm{r}$ & $\mathrm{x}$ & $\mathrm{a}$ & $\mathrm{r}$ & - & - & - & $\mathrm{x}$ & $\mathrm{a}$ & $\mathrm{r}$ & - & - & - \\
\hline Brachycaudus persicae & $\mathrm{x}$ & $\mathrm{s}$ & $\mathrm{i}$ & $\mathrm{x}$ & a & $\mathrm{r}$ & - & - & - & - & - & - & - & - & - & - & - & - \\
\hline Brevicoryne brassicae & $\mathrm{y}$ & d & $\mathrm{i}$ & $\mathrm{z}$ & d & $\mathrm{c}$ & $\mathrm{y}$ & $\mathrm{d}$ & $\mathrm{i}$ & $\mathrm{z}$ & d & $\mathrm{c}$ & $\mathrm{y}$ & d & $\mathrm{i}$ & $\mathrm{x}$ & $\mathrm{d}$ & $\mathrm{i}$ \\
\hline Capitophorus elaeagani & - & - & - & - & - & - & $\mathrm{x}$ & $\mathrm{a}$ & $\mathrm{r}$ & - & - & - & - & - & - & - & - & - \\
\hline Cinara atlantica & $\mathrm{x}$ & $\mathrm{a}$ & $\mathrm{r}$ & $\mathrm{x}$ & $\mathrm{a}$ & $\mathrm{r}$ & $\mathrm{x}$ & $\mathrm{a}$ & $\mathrm{r}$ & $\mathrm{x}$ & $\mathrm{a}$ & $\mathrm{r}$ & - & - & - & - & - & - \\
\hline Dysaphis cynarae & - & - & - & - & - & - & - & - & - & $\mathrm{x}$ & a & $\mathrm{r}$ & - & - & - & $\mathrm{x}$ & $\mathrm{a}$ & $\mathrm{r}$ \\
\hline Dysaphis emicis & - & - & - & - & - & - & - & - & - & $\mathrm{x}$ & $\mathrm{a}$ & $\mathrm{r}$ & $\mathrm{x}$ & a & $\mathrm{r}$ & - & - & - \\
\hline Eulachnus thunbergii & - & - & - & $\mathrm{x}$ & a & $\mathrm{r}$ & - & - & - & - & - & - & - & - & - & - & - & - \\
\hline Geopemphigus floccosus & - & - & - & $\mathrm{x}$ & a & $\mathrm{r}$ & - & - & - & - & - & - & - & - & - & - & - & - \\
\hline Greenidea psidii & - & - & - & $\mathrm{x}$ & $\mathrm{a}$ & $\mathrm{r}$ & - & - & - & - & - & - & - & - & - & - & - & - \\
\hline Hyperomyzus lactucae & - & - & - & - & - & - & - & - & - & $\mathrm{x}$ & a & $\mathrm{r}$ & - & - & - & $\mathrm{x}$ & $\mathrm{a}$ & $\mathrm{r}$ \\
\hline Lipaphis erysimi & - & - & - & - & - & - & - & - & - & $\mathrm{x}$ & $\mathrm{a}$ & $\mathrm{r}$ & - & - & - & - & - & - \\
\hline Macrosiphum euphorbiae & - & - & - & $\mathrm{x}$ & a & $\mathrm{r}$ & $\mathrm{x}$ & $\mathrm{a}$ & $\mathrm{r}$ & $\mathrm{x}$ & a & $\mathrm{r}$ & $\mathrm{x}$ & a & $\mathrm{r}$ & - & - & - \\
\hline Macrosiphum rosae & $\mathrm{x}$ & a & $\mathrm{r}$ & $\mathrm{y}$ & $\mathrm{s}$ & $\mathrm{i}$ & $\mathrm{x}$ & $\mathrm{a}$ & $\mathrm{r}$ & $\mathrm{x}$ & a & $\mathrm{r}$ & - & - & - & - & - & - \\
\hline Microparsus brasiliensis & - & - & - & $\mathrm{x}$ & $\mathrm{a}$ & $\mathrm{r}$ & - & - & - & - & - & - & - & - & - & - & - & - \\
\hline Myzus ornatus & - & - & - & - & - & - & - & - & - & $\mathrm{x}$ & a & $\mathrm{r}$ & $\mathrm{x}$ & a & $\mathrm{r}$ & - & - & - \\
\hline Myzus persicae & $\mathrm{y}$ & d & $\mathrm{i}$ & $\mathrm{x}$ & s & $\mathrm{i}$ & $\mathrm{y}$ & $\mathrm{d}$ & $\mathrm{i}$ & $\mathrm{z}$ & $\mathrm{d}$ & $\mathrm{c}$ & $\mathrm{x}$ & $\mathrm{a}$ & $\mathrm{r}$ & $\mathrm{x}$ & $\mathrm{a}$ & $\mathrm{r}$ \\
\hline Neophyllaphis podocarpini & - & - & - & - & - & - & $\mathrm{x}$ & $\mathrm{a}$ & $\mathrm{r}$ & $\mathrm{x}$ & a & $\mathrm{r}$ & - & - & - & $\mathrm{x}$ & $\mathrm{a}$ & $\mathrm{r}$ \\
\hline Rhopalosiphum maidis & $\mathrm{x}$ & a & $\mathrm{r}$ & $\mathrm{x}$ & a & $\mathrm{r}$ & - & - & - & $\mathrm{y}$ & a & $\mathrm{i}$ & - & - & - & $\mathrm{x}$ & $\mathrm{a}$ & $\mathrm{r}$ \\
\hline Rhopalosiphum padi & - & - & - & - & - & - & - & - & - & $\mathrm{x}$ & $\mathrm{a}$ & $\mathrm{r}$ & $\mathrm{x}$ & $\mathrm{a}$ & $\mathrm{r}$ & - & - & - \\
\hline Tetraneura nigriabdominalis & $\mathrm{x}$ & a & $\mathrm{r}$ & $\mathrm{x}$ & a & r & $\mathrm{x}$ & $\mathrm{a}$ & $\mathrm{r}$ & $\mathrm{x}$ & a & $\mathrm{r}$ & $\mathrm{x}$ & a & $\mathrm{r}$ & $\mathrm{x}$ & $\mathrm{a}$ & $\mathrm{r}$ \\
\hline Toxoptera aurantii & $\mathrm{x}$ & a & $\mathrm{r}$ & $\mathrm{x}$ & $\mathrm{a}$ & $\mathrm{r}$ & $\mathrm{x}$ & $\mathrm{a}$ & $\mathrm{r}$ & $\mathrm{x}$ & $\mathrm{a}$ & $\mathrm{r}$ & $\mathrm{x}$ & $\mathrm{a}$ & $\mathrm{r}$ & $\mathrm{x}$ & $\mathrm{a}$ & $\mathrm{r}$ \\
\hline Toxoptera citricida & $\mathrm{y}$ & $\mathrm{s}$ & $\mathrm{i}$ & $\mathrm{z}$ & d & $\mathrm{c}$ & $\mathrm{y}$ & $\mathrm{d}$ & $\mathrm{i}$ & $\mathrm{z}$ & $\mathrm{d}$ & $\mathrm{c}$ & $\mathrm{y}$ & $\mathrm{d}$ & $\mathrm{i}$ & $\mathrm{y}$ & $\mathrm{s}$ & $\mathrm{i}$ \\
\hline Tuberculatus kuricola & $\mathrm{x}$ & $\mathrm{a}$ & $\mathrm{r}$ & - & - & - & - & - & - & - & - & - & - & - & - & - & - & - \\
\hline Uroleucon ambrosiae & $\mathrm{z}$ & d & $\mathrm{c}$ & $\mathrm{z}$ & d & $\mathrm{c}$ & $\mathrm{z}$ & $\mathrm{d}$ & $\mathrm{c}$ & $\mathrm{z}$ & d & $\mathrm{c}$ & $\mathrm{y}$ & d & $\mathrm{i}$ & $\mathrm{z}$ & $\mathrm{d}$ & $\mathrm{c}$ \\
\hline Uroleucon sonchi & - & - & - & - & - & - & $\mathrm{x}$ & $\mathrm{d}$ & $\mathrm{i}$ & $\mathrm{x}$ & a & $\mathrm{r}$ & $\mathrm{x}$ & $\mathrm{a}$ & $\mathrm{r}$ & - & - & - \\
\hline n.i 1 (Aphidini) ${ }^{4}$ & - & - & - & $\mathrm{x}$ & a & $\mathrm{r}$ & - & - & - & - & - & - & - & - & - & - & - & - \\
\hline n.i 2 (Macrosiphini) ${ }^{4}$ & - & - & - & $\mathrm{x}$ & $\mathrm{a}$ & $\mathrm{r}$ & $\mathrm{x}$ & $\mathrm{a}$ & $\mathrm{r}$ & $\mathrm{x}$ & $\mathrm{a}$ & $\mathrm{r}$ & $\mathrm{x}$ & $\mathrm{a}$ & $\mathrm{r}$ & $\mathrm{x}$ & $\mathrm{a}$ & $\mathrm{r}$ \\
\hline
\end{tabular}

${ }^{1}$ Occurrence indices: $\mathrm{x}$ ) accidental; y) accessory; and z) constant; ${ }^{2}$ Dominance indices: a) accidental; s) accessory; and d) dominant; ${ }^{3}$ Status: r) rare; i) intermediary; c) common; and ${ }^{4}$ Species identified to the level of tribe.

cies collected were classified as rare, M. persicae and T. citricida were given the status of common or intermediate species in some of the orchards studied in Araucária. Although the species Myzus persicae has been cited as a peach pest (Castillo, 1993; Salles, 1998), it was not found colonizing plants. Another species, T. citricida, found in large numbers in the traps, has an occurrence associated with the phenological stage of leafy flowering of Citrus species (Cassino and Rodrigues, 2005), where it is not considered a peach pest.

The seasonal variation of the total number of aphids collected by means of Möericke traps and species clas- 


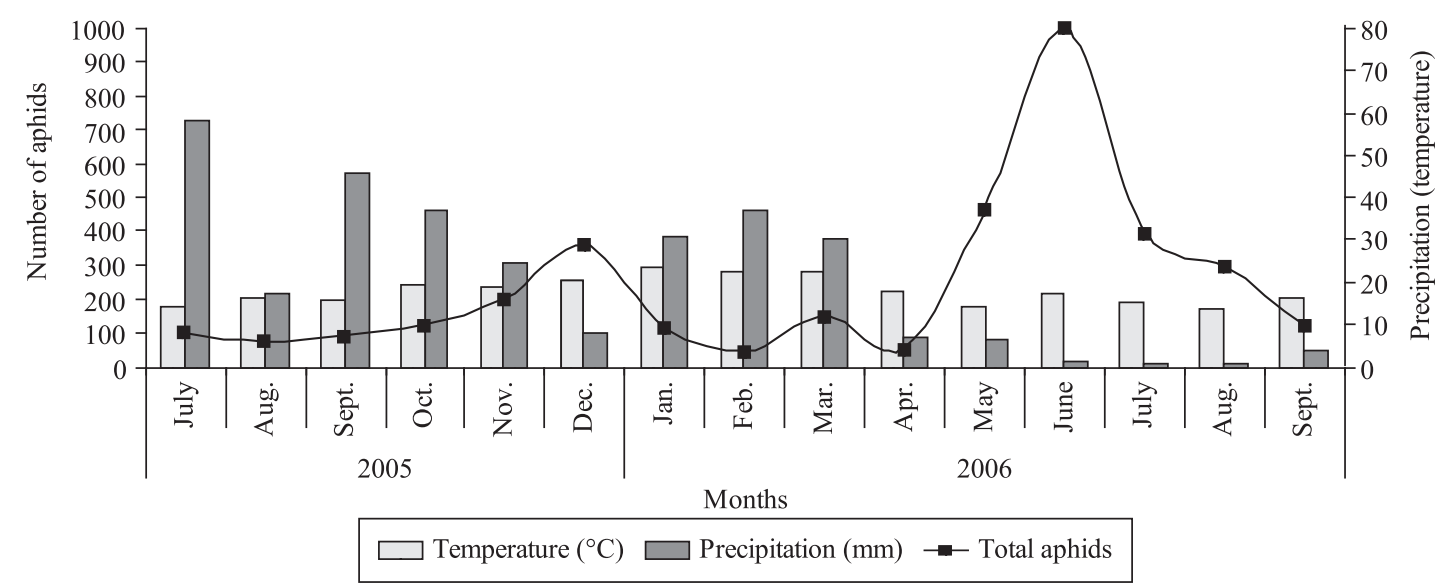

Figure 1. Population fluctuation mean of total aphids collected with Möericke traps in peach orchards. Araucária, PR. July 2005 to September 2006.

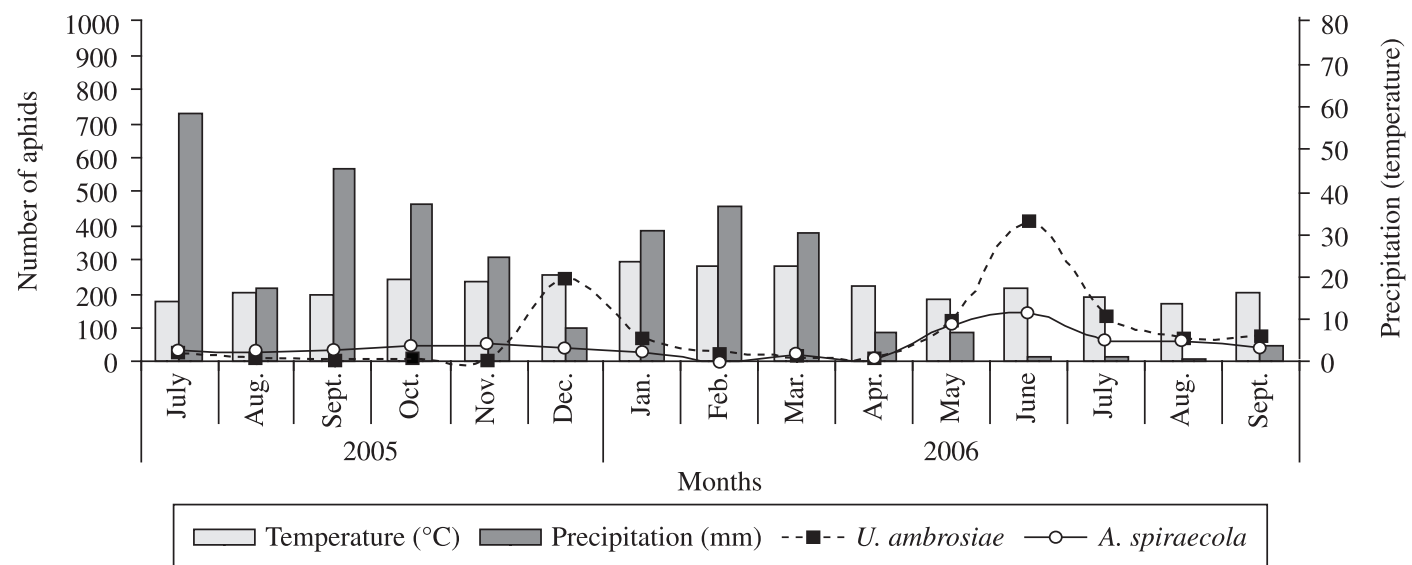

Figure 2. Population fluctuation mean of Aphis spiraecola and Uroleucon ambrosiae collected with Möericke traps in peach orchards. Araucária, PR. July 2005 to September 2006.

sified as common was inversely correlated with rainfall. These results corroborate those of other studies in the literature, in which it was concluded that prolonged periods of rain or sudden rains are unfavorable to aphids. This is because they are in unprotected places, usually on the abaxial side of the leaves, and can be washed of the plants (Imenes and Bergamann, 1984; Carvalho et al., 2002), whereas drier periods promote aphid population growth (Oliveira, 1971; Lamborot and Guerrero, 1979).

\section{References}

ABREU, PCOV. and NOGUEIRA, CR., 1989. Spatial distribution of species at Rio de Janeiro Coast Brasil. Ciência e Cultura, vol. 41, no. 9, p. 897-902.

AUAD, AM., 1996. Dinâmica populacional do pulgão-dopessegueiro Brachycaudus (Appelia) schwartzi (Börner) (Homoptera: Aphididae), em Jacuí, MG. Lavras: Universidade Federal de Lavras. 58f. Dissertação de Mestrado.
BARTOSZECK, AB., 1976. Afídeos da ameixeira (Prunus domestica) e pessegueiro (Prunus persica), seus predadores e parasitas. Acta Biologica Paranaense, vol. 5, no. 1-2, p. 69-90.

BLACKMAN, RL. and EASTOP, VF., 1984. Aphids on the World's Crops: an identification guide. New York: Wiley and Sons. 466p.

BOTTON, M., ARIOLI, CJ., BAVARESCO, A. and SCOZ, PL., 2003. Sistema de produção de pêssego de mesa na região da Serra Gaúcha: principais pragas. Bento Gonçalves: Embrapa Uva e Vinho. 1 CD-ROM

CARVALHO, LM., BUENO, VHP. and MARTINEZ, RP., 2002. Levantamento de afídeos alados em plantas hortícolas em Lavras, MG. Ciência e Agrotecnologia, vol. 26, no. 3, p. 523-532.

CASSINO, PCR. and RODRIGUES, WC., 2005. Distribuição de insetos fitófagos (Hemiptera: Sternorrhyncha) em plantas cítricas no Estado do Rio de Janeiro. Neotropical Entomology, vol. 34, no. 6, p. 1017-1021.

CASTILLO, MPG., 1993. Áfidos del duraznero (Prunus persicae Batsch) en la región sureste de Durango y noroeste de Zacatecas. In: SANTIAGO, GP. and GUTIERREZ, MCG. 
(Eds.). Áfidos de importancia agrícola en México. México: [s.n.]. p. 179-181.

COSTA, C., EASTOP, VF. and BLACKMAN, RL., 1993. Brazilian Aphidoidea: I. Key to families, subfamilies and account of the Phylloxeridae. Pesquisa Agropecuária Brasileira, vol. 28 , no. 2, p. 197-215.

FERREIRA, RG. and BARBOSA, FR., 2002. Ocorrência de afídeos causando danos em mangueira (Mangifera indica L.), no Vale do São Francisco. Revista Brasileira de Fruticultura, vol. 24 , no. 1 , p. $267-268$.

FOOTTIT, RG. and RICHARDS, W., 1993. The genera of aphid of Canadá, Homoptera: Aphidoidea and Phylloxeroidea. Ottawa: Agriculture Canadá. 766p.

GALLO,D., NAKANO, O., SILVEIRA NETO, S., CARVALHO, RPL., BATISTA, GC., BERTI FILHO, E., PARRA, JRP., ZUCCHI, RA., ALVES, SB. and VENDRAMIM, JD., 2002. Entomologia agrícola. São Paulo: Ceres. 646p.

GUALTIERI, LL. and Mc LEOD, DGR., 1994. Atlas of aphids trapped in agricultural crops. Ottawa: Agriculture and AgriFood Canadá. 66p.

HOLMAN, J., 1974. Los áfidos de Cuba. Habana: Instituto Cubano del Libro. 304p.

IMENES, SD. and BERGAMANN, EC., 1984. Estudo da fauna afidológica em cultura de tomateiro. O Biológico, vol. 50, no. 7, p. $157-161$

JUNQUEIRA, AH. and PEETZ, MS., 2003. Aspectos relevantes do mercado interno e externo. In RASEIRA, MCB. and QUESADA, AC. (Eds.). Pêssego: produção. Brasília: Embrapa Informação Tecnológica. 160p.

LAMBOROT, CHL. and GUERRERO, SMA., 1979. Dinâmica populacional de los afídeos de cereales y sus inemigos naturales in la Provincia de Santiago durante lãs temporadas 1976 y 1977. Investigacion Agricola, vol. 5, no. 1, p. 23-32.

LAZZARI, SMN., 1985. Inimigos naturais dos afídeos (Homoptera, Aphididae) da cevada (Hordeum sp.) no Paraná. Anais da Sociedade Entomologica do Brasil, vol. 14, no. 1, p. 5-15.

LAZZARI, SMN. and LAZZAROTTO, CM., 2005. Distribuição altitudinal e sazonal de afídeos (Hemiptera: Aphididae) na serra do Mar, Paraná, Brasil. Revista Brasileira de Zoologia, vol. 22, no. 4, p. 891-897.

MANSUR, PS., 1971. Contribuição ao conhecimento dos pulgões (Homoptera: Aphididae), que ocorrem em pessegueiro no Estado de São Paulo, Brasil. Piracicaba: Universidade de São Paulo. 37f. Dissertação de Mestrado.

MARTIN, JH., 1983. The identification of common aphid pests of tropical agriculture. Tropical Pest Management, vol. 29, no. 4, p. $395-411$.

OLIVEIRA, AM., 1971. Observações sobre a influência de fatores climáticos nas populações de afídeos em batata. Pesquisa Agropecuária Brasileira, vol. 6, no. 1, p. 163-172.

SALLES, LAB., 1998. Principais pragas e seu controle. In Empresa Brasileira de Pesquisa Agropecuária, Centro Nacional de Pesquisa de Fruteiras de Clima Temperado, Cultura do pessegueiro. Pelotas: Comitê de Publicações. 350p.

SIMEPAR. Dados históricos da rede telemétrica hidrometeorológica do SIMEPAR. Disponível em: <http:// www.simepar.br/>. Acesso em: 30 de Outubro de 2006.

SOUZA-SILVA, CR. and ILHARCO, FA., 1995. Afídeos do Brasil e suas plantas hospedeiras (lista preliminar). São Carlos: EDUFSCar. 85p.

WEBB, SE., KOK-YOKOMI, ML. and VOEGTLIN, DJ., 1994. Effect of trap color on species composition of alate aphids (Homoptera: Aphididae) caught over watermelon plants. Florida Entomologist, vol. 77, no. 1, p. 146-154. 